\title{
MEMÓRIA E NARRAÇÃO NA TRADUÇÃO TELEVISIVA DE DOIS IRMÃOS ${ }^{1}$
}

\author{
Letícia Xavier de Lemos Capanema ${ }^{2}$
}

\begin{abstract}
Resumo: Este artigo busca examinar aspectos da adaptação televisiva do romance Dois Irmãos (Milton Hatoum, 2000), realizada por Luiz Fernando Carvalho (direção) e Maria Camargo (roteiro) e exibida pela Rede Globo em 2017. Em particular, coloca-se em relevo as relações entre memória, esquecimento e narração presentes no livro e traduzidas para a minissérie homônima. Para isso, realiza-se uma reflexão sobre a noção de adaptação enquanto tradução, no sentido da transposição criativa entre formas expressivas distintas, tendo por base o conceito de tradução intersemiótica de Julio Plaza. As observações sobre a memória e a narração, mobilizadas pelo texto de Hatoum e pela minissérie de Carvalho e Camargo, são fundamentadas nas ideias de Walter Benjamin e de seus comentadores.
\end{abstract}

Palavras-chave: ficção televisiva; adaptação; tradução; memória; Dois Irmãos.

Abstract: This article aims to analyze aspects of the television adaptation of the novel Dois Irmãos (Milton Hatoum, 2000) by the director Luiz Fernando Carvalho and the screenwriter Maria Camargo and aired by Rede Globo in 2017. In particular, we focus on the relations between memory and narration proposed by the book and translated for the TV mini-series. For this purpose, this study reflects on the notion of adaptation as translation, in the sense of creative transposition between different expressive forms, based on Julio Plaza's intersemiotic translation concept. The observations on memory and narration, mobilized by the text of Hatoum and by the mini-series of Carvalho and Camargo, are based on the ideas of Walter Benjamin.

Keywords: TV fiction; adaptation; translation; memory; Dois Irmãos.

\section{Literatura, televisão e uma certa compreensão da adaptação}

A relação entre literatura e televisão remonta os primórdios da teledramaturgia brasileira. A contar dos tempos do teleteatro ao vivo (anteriores ao videotape) às recentes adaptações de contos e romances no formato de telenovelas, séries e minisséries, a literatura tem se mostrado uma inesgotável fonte de inspiração para a produção ficcional televisiva. É dessa longa história das relações entre a literatura e a televisão que destacamos a minissérie Dois Irmãos, adaptação do romance homônimo de Milton Hatoum, realizada sob a direção artística de Luiz Fernando Carvalho e roteiro de Maria Camargo e exibida em 2017 pela Rede Globo de Televisão. Dois Irmãos é uma adaptação realizada dentro do escopo do Projeto

\footnotetext{
${ }^{1}$ Trabalho apresentado no XXI Encontro da Sociedade Brasileira de Estudos de Cinema e Audiovisual SOCINE, realizado na Universidade Federal da Paraíba, no período de 17 a 20 de outubro de 2017.

${ }^{2}$ Doutora em Comunicação e Semiótica pela PUC/SP e professora titular do curso de graduação em Cinema e Audiovisual da UFMT.
} 
Quadrante $^{3}$, que consiste na adaptação televisiva de importantes obras da literatura brasileira provenientes de quatro estados do território nacional.

Representando a Paraíba, o Projeto teve início com A Pedra do Reino (2007), minissérie oriunda da obra $O$ Romance da Pedra do Reino e O Príncipe do Sangue do Vai e Volta, de Ariano Suassuna. O Rio de Janeiro foi retratado em Capitu (2008), adaptação de Dom Casmurro, de Machado de Assis. Quase dez anos depois, representando o Amazonas, foi realizada a minissérie Dois Irmãos (2017). Dançar Tango em Porto Alegre, de Sérgio Faraco, é a quarta adaptação ainda a ser produzida, sendo a obra escolhida para representar o Rio Grande do Sul.

O Projeto Quadrante presta-se a um empreendimento audacioso, de pretensões mais arrojadas do que costuma-se encontrar na televisão. Além de investir na adaptação de obras literárias, o projeto propõe uma sofisticada direção artística (por vezes criticada como hermética demais para o telespectador) e uma certa concepção de adaptação, ambas encabeçadas por Luiz Fernando Carvalho.

Embora as três adaptações, até o momento realizadas, abordem universos narrativos muito distintos entre si, elas compartilham o tom operístico, teatral e barroco, marcas de autoria de Carvalho que perpassam atuação, direção de arte, montagem e trilha sonora. Ademais, o Projeto realiza as gravações das minisséries nas regiões onde as histórias são contextualizadas, incluindo elenco e profissionais locais.

No que concerne a noção de adaptação, o Projeto segue a via da recriação poética, que é conduzida de maneira singular por Carvalho e sua equipe. De fato, o diretor possui uma significativa experiência com a tradução de obras literárias para a linguagem audiovisual. Fora o Projeto Quadrante, Carvalho já realizou adaptações para o cinema e para a televisão de obras de escritores como Raduan Nassar, Eça de Queirós, Roland Barthes, Clarice Lispector, Graciliano Ramos, entre outros. Em entrevista, o diretor sintetiza sua visão sobre a adaptação, alegando buscar "um diálogo com a literatura" capaz de criar "uma terceira linguagem". Segundo Carvalho, o grande desafio desse diálogo é "não transformar a potência da linguagem do romance em uma mera adaptação"

\footnotetext{
${ }^{3}$ O Projeto Quadrante foi incorporado ao projeto Assista a Esse Livro, que consiste em diversas ações (realização de minisséries, publicações, seminários e encontros) com objetivo de promover a literatura nacional através da teledramaturgia. Projeto Quadrante: http://quadrante.globo.com/

Assista a Esse Livro: http://globouniversidade.globo.com/projetos/assista-a-esse-livro

${ }^{4}$ Trechos da entrevista de Luiz Fernando Carvalho cedida ao crítico de televisão Mauricio Stycer a propósito da minissérie Dois Irmãos. A entrevista completa pode ser consultada no link:
} 
Esse empenho em gerar uma terceira linguagem, ao qual se refere Carvalho, é justamente o modus operandi que rege os processos de adaptação literária desse realizador. Ir além da mera adaptação significa ultrapassar o que é informação no romance e alcançar aquilo que nele é poesia e sensibilidade. Tal perspectiva, exposta nas entrevistas e nos trabalhos do diretor, encontra ressonância nas concepções da adaptação geradas pela narratologia contemporânea, pela semiótica e por certas vertentes da teoria da tradução.

Nosso objetivo neste artigo é, portanto, examinar alguns aspectos da adaptação televisiva de Dois Irmãos, particularmente aqueles que tocam a relação entre memória, esquecimento e narração presente no livro e traduzida para a minissérie. Nossa hipótese é que a versão televisiva de Dois Irmãos, ao privilegiar a transposição de sensibilidades e sensações em detrimento da noção de "fidelidade" às informações do livro, inscreve-se na perspectiva que compreende a adaptação enquanto tradução criativa. Para verificar nossas suposições, num primeiro momento, buscaremos nos aprofundar no conceito de tradução, apoiando-nos nas reflexões de Robert Stam (2006) sobre os perigos da noção de "fidelidade" no processo adaptativo, na ideias de Julio Plaza (2013) sobre a tradução intersemiótica e no conceito de transcriação de Haroldo de Campos (1987). As reflexões de Anna Maria Balogh (2004) serão levantadas especialmente no que concerne à tradução de textos literários para o modo de realização da televisão. Em seguida, apresentaremos o romance que deu origem à minissérie assim como a maneira pela qual memória, esquecimento e narração são nele desenhadas. Por fim, examinaremos certos artifícios utilizados pela minissérie para recriar o desenho dessa relação por meio da linguagem audiovisual. As associações entre memória e narração, mobilizadas pelo texto de Hatoum e pela tradução televisiva de Carvalho e Camargo, serão examinadas a partir das reflexões de Walter Benjamin e de seus comentadores. Nossas investigações nos levam a argumentar que a minissérie Dois Irmãos se inscreve em uma certa perspectiva da adaptação conduzida por Luiz Fernando Carvalho e equipe na execução do Projeto Quadrante. Perspectiva essa que se caracteriza justamente pela tradução, entendida como recriação poética da literatura para a televisão.

https://mauriciostycer.blogosfera.uol.com.br/2017/01/09/dois-irmaos-supera-o-desafio-de-adaptar-um-otimolivro-e-voa-longe-na-tv/ 


\section{Adaptação enquanto tradução criativa}

No campo das artes narrativas, como a literatura, o cinema, o teatro e a teledramaturgia, recorre-se ao termo adaptação para nomear o processo de realização de enredos e argumentos não originais, isto é, derivados de obras precedentes. Contudo, os estudos contemporâneos da adaptação têm gerado o questionamento do termo em sua capacidade de expressar a complexidade do processo de transposição de uma narrativa de uma forma expressiva a outra.

Robert Stam, por exemplo, ressalta a tendência moralista e hierárquica na maneira de vislumbrar o processo de adaptação. Segundo ao autor, ainda persiste a noção de subordinação da obra adaptada à obra original, à qual se deve fidelidade. No âmbito da adaptação de um livro para o cinema ou para a televisão, é recorrente o discurso que "reinscreve a superioridade axiomática da literatura" sobre as formas audiovisuais, "lamentando o que foi 'perdido' na transição (...) ao mesmo tempo em que ignora o que foi 'ganhado' " (STAM, 2006, p. 20). Nesse sentido, as noções de fidelidade e infidelidade da obra adaptada à sua correspondente original podem ofuscar aspectos relevantes do processo adaptativo.

Atentos a essas questões, os estudos da adaptação, particularmente após o impacto da narratologia estruturalista e pós estruturalista ${ }^{5}$, têm acumulado uma vasta terminologia para nomear, com mais justiça, o processo de migração entre formas expressivas. Nesse sentido, a adaptação passa a ser compreendida enquanto leitura, re-escritura, tradução, intertextualidade, metacriação, transcriação entre outros termos. Cada um deles ressalta determinados aspectos do processo de adaptação. Embora Stam privilegie o termo intertextualidade, embasado nas ideias de Bakhtin e de Genette, elegemos a tradução como palavra capaz de expressar, de maneira mais precisa, os deslocamentos da narrativa entre distintos sistemas sígnicos. Afinal, interessa-nos não apenas compreender o dialogismo entre "textos", mas, igualmente, a transmutação de um texto para outro sistema de linguagem.

O tema da tradução entre sistemas sígnicos foi explorado com bastante pertinência por Julio Plaza, teórico e artista intermídia que se dedicou à compreensão da tradução intersemiótica, a partir de práticas artísticas em diversas linguagens e suportes midiáticos.

\footnotetext{
${ }^{5}$ Durante os anos 1960 e 1970, os estudos da intertextualidade de Julia Kristeva (baseados nas idéias de Bakhtin) e também aqueles de Gérad Genette mobilizaram novas visões sobre as relações entre "textos". O autor passa a ser visto como orquestrador de discursos pré-existentes e a originalidade das obras passa a ser relativizada. Ademais, a narratologia alarga seu interesse em direção a outras mídias além da literatura, como o cinema, a televisão e as histórias em quadrinhos, valorizando suas propriedades inerentes.
} 
Para o autor "a operação tradutora como trânsito criativo de linguagens nada tem a ver com a fidelidade" (2013, p. 1). Isso porque ela cria sua própria verdade, em uma relação tecida entre linguagens e entre temporalidades (passado-presente-futuro). O compromisso da tradução não é com a fidelidade, mas com sua coerência interna enquanto processo de interpretação, apropriação e recriação de uma obra situada no passado, mas que dialoga com o presente. Nesse sentido, valoriza-se a abertura e o inacabamento da obra original, como possibilidade de tradução daquilo que dela exala pelos poros da linguagem. Uma obra pode ter tantas leituras quanto maior for sua capacidade de abertura e quantas forem as luzes interpretativas lançadas sobre ela.

Haroldo de Campos, por sua vez, propõe o termo transcriação como aquele capaz de expressar a complexidade do processo de tradução. Para o autor, a "tradução de textos criativos será sempre recriação". No processo de transcriação "não se traduz apenas o significado, traduz-se o próprio signo" (CAMPOS, 1992, p.35). A tradução apresenta-se, portanto, como uma forma mais atenta de ler. Uma leitura preocupada em interpretar não apenas aquilo que é objetivo, mas também (e talvez principalmente), aquilo que escapa à objetividade. Trata-se assim de uma tradução poética, que se volta justamente para o inacabamento da obra, suas fissuras, suas insinuações, suas sensações, sua poesia, sua iconicidade.

No contexto da tradução de uma narrativa literária para a forma expressiva audiovisual, coloca-se em jogo o desafio de transmitir sensações em outra linguagem que, originalmente, não lhe pertencia. Nas palavras de Robert Stam, trata-se de adaptações que "redistribuem energias, provocam fluxos e deslocamentos; a energia lingüística do texto literário se transforma em energia áudio-visual-cinética-performática da adaptação" (2006, p. 50). Traduzir é, nessa medida, identificar e interpretar as leis que configuram uma obra para transmutá-las numa nova configuração linguageira.

Walter Benjamin, em sua reflexão sobre A Tarefa do Tradutor, argumenta que uma obra contém, certamente, uma carga de informação objetiva, mas pode também carregar atributos não objetivos, que precisam ser igualmente traduzidos. $\mathrm{O}$ bom tradutor seria aquele que não se limita à informação, mas que alcança, interpreta e traduz sensibilidades e sensações. 
É nesse sentido que encontramos ressonâncias entre as concepções de tradução criativa e as experiências realizadas por Luiz Fernando Carvalho e equipe dentro do Projeto Quadrante. Interessa-nos examinar, justamente, a capacidade dessas obras televisivas de captar e traduzir a literariedade, a poesia e as evocações sensórias de um romance (naquilo que nele é sensibilidade e inacabamento), valendo-se de recursos da linguagem audiovisual e criando, assim, outra obra poética. É a partir dessa perspectiva que propomos analisar aspectos da tradução do livro Dois Irmãos para a forma de minissérie televisiva.

\section{Dois irmãos, uma história sobre a memória e o esquecimento}

Sabemos que a tradução implica a reconfiguração de uma forma. Portanto, ela pressupõe a consciência, em alto grau, da linguagem e da poética que rege a obra primeira. Para alcançar essa consciência é preciso regressar ao original "pois nele está contida sua lei, assim como a possibilidade de sua tradução" (BENJAMIN, 2008, p.83).

Em linhas gerais, Dois Irmãos conta a trágica saga de uma família de imigrantes libaneses instalados na cidade de Manaus, entre as décadas 1920 e 1980. Zana e Halim são pais de Rânia e dos gêmeos Yaqub e Omar. O clã mora em um sobrado nas proximidades do porto de Manaus. No casebre dos fundos, vivem a índia Domingas, criada da família, e seu filho Nael. A vida da família e de seus empregados é afetada pela violenta rivalidade entre os gêmeos, desencadeada pela preferência quase incestuosa de Zana por Omar. A história é narrada por Nael, filho de Domingas e, possivelmente, de um dos gêmeos. A lembrança do que viveu e das histórias que ouviu, temperada pelo ressentimento de filho bastardo e pela busca de sua paternidade, dá o tom da narração. Fatos históricos e transformações da cidade de Manaus se entrelaçam à trágica decomposição da família em uma narrativa não linear, repleta de reflexões sobre o tempo, a memória, a amargura, o amor desmesurado e o ressentimento.

São diversas as portas de acesso ao rico universo de Dois Irmãos. As inúmeras possibilidades de interpretação do romance parecem evocar a qualidade dos clássicos, essa capacidade de não cessar de dizer tudo aquilo que tem a dizer. De fato, Dois Irmãos aborda uma pluralidade de dramas: a rivalidade entre gêmeos, a tragédia familiar, o incesto, a relação conflituosa entre pais e filhos, a chegada de imigrantes no norte do Brasil, a dominação e catequização dos índios, a Segunda Guerra Mundial, o golpe militar de 1964, a emergência da 
zona franca de Manaus, entre outros. Contudo, mais do que uma tragédia universal ou um drama social e histórico, Dois irmãos é, acima de tudo, uma história sobre a memória.

Além da releitura do mito de Caim e Abel (ou de Esaú e Jacó), o romance de Hatoum volta-se sobre como a percepção da memória do narrador desenha a personalidade dos irmãos. Talvez a beleza desse romance resida justamente na relação entre memória, esquecimento e narração, tão habilmente tecida na figura de Nael.

Assim como Dom Casmurro, romance de Machado de Assis também adaptado para televisão por Carvalho, Dois Irmãos é uma história narrada a partir de lembranças. Se em Dom Casmurro o narrador tenta restaurar na velhice aquilo que fora na adolescência, para assim reviver as sensações da juventude, em Dois Irmãos, Nael narra para compreender de onde veio e, assim, constituir sua identidade. A narração da memória, em Dois Irmãos, caminha em paralelo à construção de Nael enquanto personagem e sujeito. À medida que a narrativa avança, o narrador, inicialmente distante e anônimo (um filho de ninguém), cresce e torna-se um personagem central, presente e complexo.

De fato, como afirma a estudiosa do pensamento de Benjamin, Jeanne Marie Gagnebin, “a questão da memória é inseparável de uma reflexão sobre narração. (...) E as formas de lembrar e de esquecer, como as de narrar, são os meios fundamentais da construção da identidade, pessoal, coletiva ou ficcional" (2014, p. 218). Nesse sentido, é através de lembranças e esquecimentos que Nael narra em busca de suas origens, de algo que lhe falta para constituir-se como sujeito.

Nael é um personagem no limiar. Ele se encontra entre duas casas (a dos patrões e a dos empregados), duas culturas (a libanesa e a indígena), duas possíveis paternidades (Omar e Yaqub). Ele é o filho bastardo da família à qual pertence e ao mesmo tempo não pertence. É o narrador de uma história da qual faz e não faz parte. Está na soleira, ao mesmo tempo dentro e fora. É ele quem dá voz à memória de Halim e à de Domingas, tecidas junto às suas próprias lembranças e a acontecimentos históricos. Segundo Hatoum, eleger Nael como narrador foi "uma escolha ética, mas não ideológica. Nael é um mestiço, filho de uma índia com um brasileiro de origem árabe. E ele, Nael, será a memória da tribo" (2017, p. 17).

A memória construída pela narração de Nael configura-se, portanto, como uma espécie de mosaico de lembranças pessoais, alheias, coletivas e históricas filtradas pela 
percepção do narrador e agrupadas numa tentativa de "recompor a tela do passado ${ }^{6}$." Vale frisar que, segundo Benjamin, "articular o passado não significa conhecê-lo 'tal como ele foi de fato'. Significa apropriar-se de uma recordação, como ela relampeja no momento de um perigo" (2012, p. 243). Esse momento de perigo é o presente da narração. Nael narra na vida adulta, após a morte de parte dos personagens e após transformações ocorridas na casa, em Manaus, no Brasil e no mundo.

Assim como em Dom Casmurro, o encanto de Dois Irmãos não é o desfecho objetivo do enredo: Capitu traiu ou não traiu; Nael é filho de um ou de outro. Pelo contrário, a beleza da narração da memória é a dúvida. Em Dois Irmãos, mais importa compreender os mecanismos da memória que esclarecer a paternidade do narrador. Em outras palavras, a tentativa de reconstrução do passado e a tensão da dúvida são processos narrativamente mais ricos que a informação acabada de quem é o pai de Nael.

Sem abandonar o enredo e os diversos temas que o perpassam, a tradução televisiva de Dois Irmãos, realizada por Luiz Fernando Carvalho e Maria Camargo, é conduzida justamente pelo diálogo entre memória e narração. Segundo Carvalho, o olhar silencioso, ressentido e atento de Nael é "pura linguagem" (2017, p. 26) e é a partir do mergulho nesse olhar que é tecida a tradução poética de Dois Irmãos.

\section{Aspectos de uma poesia audiovisual da memória}

Embora seja possível, como fizemos, descrever os temas e o enredo do romance, como traduzir os humores dessa família em decomposição? A amargura da rejeição? O silêncio ressentido de Yaqub? O amor louco e exacerbado de Zana? As lembranças que escorrem do olhar de Halim? A força insuperável do tempo e a finitude das coisas, traçadas pela memória e pelo esquecimento na narração de Nael?

Mais importante que reproduzir as ações apresentadas no livro, a tradução preocupa-se em compreender as leis poéticas que regem a obra. Somente após dominá-las, é possível delas se apropriar e assim, remodelá-las em outra linguagem. A adaptação enquanto tradução criativa significa assimilar o intraduzível, para dele se apossar e recriar.

\footnotetext{
${ }^{6}$ Narração de Nael presente no livro e transposta para minissérie: "(Halim) contava esse e aquele caso, dos gêmeos, de sua vida, de Zana, e eu juntava os cacos dispersos, tentando recompor a tela do passado.” (2017, p.134)
} 
Benjamin ressalta que uma das funções da tradução é justamente "dar expressão à relação mais íntima das línguas umas com as outras" (2008, p.85). Na esteira desse raciocínio, expandimos essa reflexão para traduções entre sistemas sígnicos distintos. Dessa maneira, podemos inferir que a tradução intersemiótica, mais do que evidenciar as diferenças entre os sistemas sígnicos, joga luz sobre aquilo que as linguagens compartilham, ainda que por meios distintos: a capacidade de expressar o intraduzível. É desse paradoxo que nasce a tradução.

Entretanto, ao tratar da transposição de um romance para a televisão, torna-se incontornável refletir sobre as diferenças entre a linguagem literária e a televisiva. É verdade que o audiovisual vale-se de uma gramática própria para se comunicar com o espectador, diversa daquela que a palavra escrita estabelece com o leitor. Como nos lembra Anna Maria Balogh, a transposição de obras literárias para a televisão implica estratégias complexas já que, no âmbito da TV, “o sujeito empírico da Enunciação se estilhaça numa vasta equipe de profissionais, sendo que cada um deles submete o roteiro a um 'filtro' específico de seu fazer de base (roteiro, direção, fotografia...)” (2002, p.130-131). Os mecanismos da narração tornam-se mais intrincados no cinema e na televisão na medida em que a narrativa audiovisual manifesta-se por meio de um sistema pluri-expressivo (verbal, sonoro e visual). A narração, por exemplo, que no romance emerge de maneira mais nítida por meio da "voz do narrador", no audiovisual torna-se diluída, apresentado-se não somente pela via do verbo, mas também da imagem, do som e da montagem.

É nesse sentido que a elaboração do roteiro de Dois Irmãos, por Maria Camargo, apropriou-se das leis poéticas do romance para criar sua própria poesia por meio da linguagem audiovisual. De acordo com a roteirista: "Se pegasse as palavras do Milton (Hatoum) e fizesse a cena como escrita no livro, não funcionaria na TV. Tive de me apropriar da história e torná-la minha, senão não conseguiria” (2017, p. 27). Assim é que parte da voz de Nael transforma-se, na minissérie, em imagem, ação, gesto, cor, textura, música, sonoplastia e montagem.

Cenas que não existiam no romance são incluídas na adaptação. Outras são suprimidas ou transformadas. Podemos citar, por exemplo, a cena, inexistente no livro, em que as mãos de Zana hesitam em soltar as do filho preferido, Omar, enquanto Yaqub, ressentido pela rejeição, observa a mãe e o irmão do navio que o levará para o Líbano (FIG. 1). O início de uma separação que duraria cinco anos. Um momento crucial do enredo que ganha contornos 
de poesia através da orquestração de gestos, olhares, música e decupagem, sem o suporte da voz do narrador.

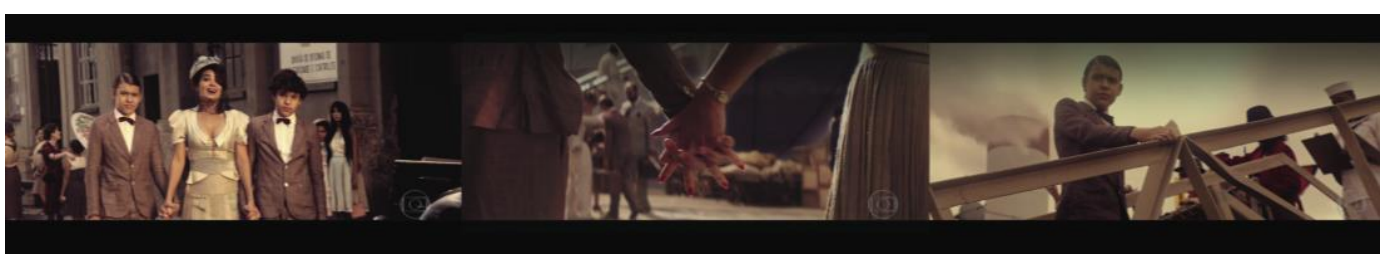

FIGURA 1. Frames que representam a cena da despedida entre Zana e seu filho Yaqub que embarca para o Líbano, separando-se da família por cinco anos. FONTE: Dois Irmãos (Rede Globo, 2017)

Outro belo exemplo de apropriação para recriação consiste nas cenas em que Halim conta a Nael suas lembranças do passado. No livro, essas conversas ocorrem, em sua maioria, na loja de Halim. Na minissérie, elas se desenvolvem em um longo percurso de barco pelo Rio Negro (FIG. 2). Uma bela metáfora dessa "capacidade infinita de lembrar e de contar" (GAGNEBIN, 2014, p. 219) que Walter Benjamim compara a um rio, e que a minissérie dela se apropria para melhor expressar sua poesia.

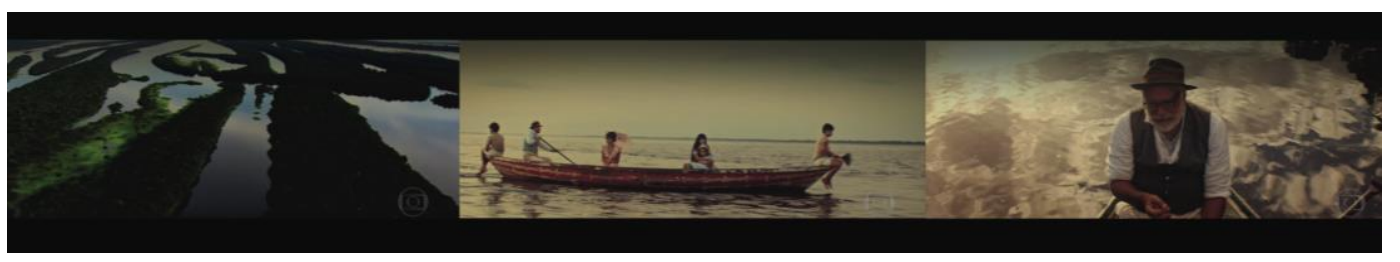

FIGURA 2. Os Frames são exemplos da presença do rio na minissérie e sua associação à memória e à narração. FONTE: Dois Irmãos (Rede Globo, 2017)

Para tratar das questões da memória e da narração colocadas pelo romance e traduzidas para a linguagem audiovisual pela minissérie, destacamos certos aspectos que nos parecem mais evidentes e pertinentes. São eles: o uso da água como representação da memória e como elemento catalisador da lembrança; a ruína como alegoria da memória esculpida pelo tempo e pelo esquecimento; e o entrelaçamento entre memória individual e memória coletiva.

\section{Água como metáfora da memória}

A paisagem ficcional de Dois Irmãos é composta de rios, palafitas, barcos e muita chuva. Embora o livro apresente a água como elemento constituinte de sua diegese, é na 
adaptação televisiva que ela é tratada mais nitidamente como metáfora da memória. Além da já citada associação entre o rio e o ato de rememorar, encontramos na minissérie uma cenografia repleta de espelhos d'água, poças e chuvas. Elementos fluidos e especulares que, como a memória, refletem uma realidade disforme. Na minissérie, a água, em suas diversas formas, apresenta-se como uma espécie de catalisadora da memória e suas distorções do passado.

Narrador consciente da potência dessa imagem, Nael chama atenção para "a chuva que embaça os olhos, mas desperta a memória"”. De fato, na versão televisiva, é a chuva que provoca certas memórias involuntárias de Halim e Domingas. A montagem dos planos se beneficia desse artifício para articular os deslocamentos temporais de um enredo não cronológico. Como ocorre na cena em que Domingas, ainda criança, chega pela primeira vez à casa de Zana e tem seus pés lavados pela patroa. Ela observa a água que escorre da vasilha. O som e a imagem da água despertam a memória involuntária da menina, evocando a lembrança de quando nadava nua no rio junto a outras índias (FIG. 3).

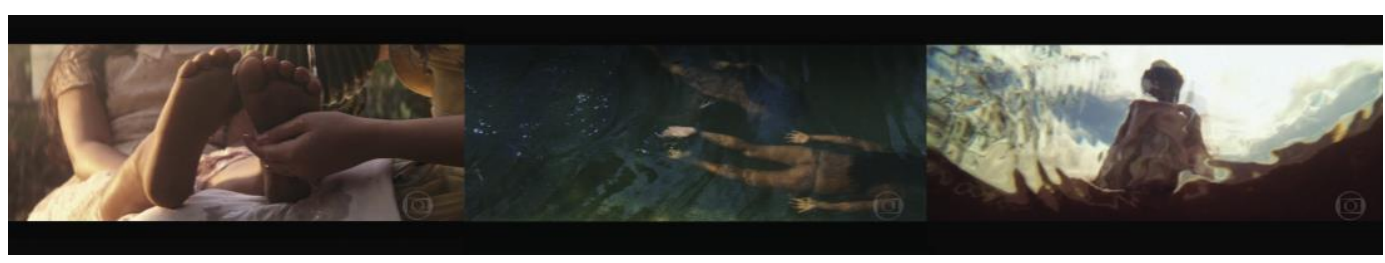

FIGURA 3. Frames retiradas da minissérie que ilustram a presença água em suas diversas formas e suas associações à memória. FONTE: Dois Irmãos (Rede Globo, 2017)

As passagens entre presente e passado, evocadas pela imagem da água, parecem nos lembrar de que "o principal, para o autor que rememora, não é absolutamente o que ele viveu, mas o tecido de sua rememoração, o trabalho de Penélope da reminiscência” (BENJAMIN, 2012, p. 38). Em outras palavras, mais que acessar um passado já posto e definido, mais importa, na rememoração, compreender a reconfiguração do passado no presente, mesmo que ele apresente-se "fantasiado pelo tempo e sua vozes".

\section{Ruínas da memória}

A vinheta de abertura da minissérie é composta de pinturas de Carlos Araújo (FIG. 4). Há quarenta anos, o artista havia realizado uma série de quadros que representam figuras

\footnotetext{
${ }^{7}$ Frase dita pela narração de Nael no primeiro capítulo da minissérie.

${ }^{8}$ Frase dita por Halim no quinto capítulo da minissérie.
} 
humanas (algumas são mães segurando seus filhos) por meio de traços fortes e dramáticos, com contornos disformes, tons monocromáticos e textura desgastada.

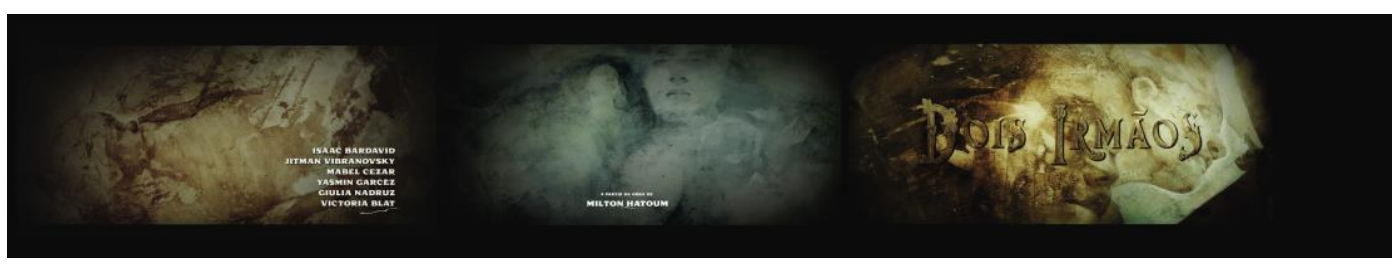

FIGURA 4. Frames da vinheta de abertura da minissérie. FONTE: Dois Irmãos (Rede Globo, 2017)

Difícil não associar o traço de Araújo às paredes centenárias, manchadas e descascadas do sobrado de Zana e Halim. Como um palimpsesto da memória, as paredes da casa são ruínas onde o tempo imprimiu manchas e marcas, desenhando as sombras, os desejos, os pecados e os arrependimentos de uma família em decomposição. Associados ao universo narrativo da minissérie, as imagens da abertura, que surgem em movimentos suaves e acompanhadas por uma ópera trágica, podem ser interpretadas como o processo de crescimento dos filhos imbuídos pelo amor desmesurado de Zana e sua preferência por um dos gêmeos. As imagens da figura materna e seus filhos apresentam-se de maneira visceral pelos traços do artista. São figuras que parecem corroídas pelo tempo, como as manchas da casa que, silenciosa, assiste à trágica decadência da família até o destruição total de suas paredes (FIG. 5).

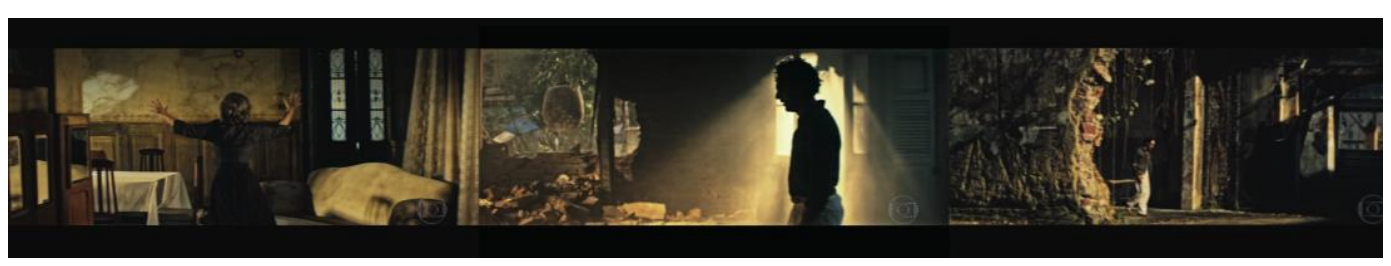

FIGURA 5. Frames que representam as ruínas da casa de Zana e Halim. FONTE: Dois Irmãos (Rede Globo, 2017)

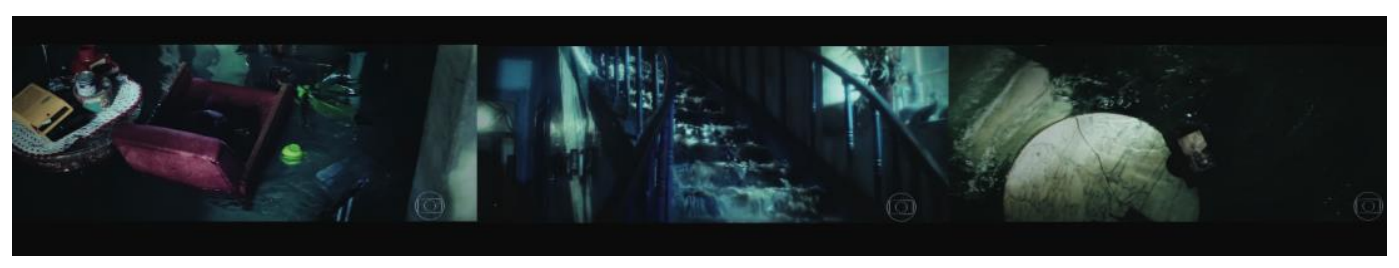

FIGURA 6. Frames que ilustram a destruição provocada pela inundação da casa de Zana e Halim. FONTE: Dois Irmãos (Rede Globo, 2017) 
O sobrado de Zana e Halim é como um personagem. A decadência dessa casa representa não só o fim da família, mas também o esquecimento das narrativas que nela foram vivenciadas. No fim da vida, Zana enxerga seus mortos em cômodos, móveis e paredes da casa. Ao observar o sobrado onde viveu com seu pai, casou-se e criou seus filhos, Zana vê a casa ruir pela ação do tempo e da chuva. Inundações destroem paredes, submergem móveis e objetos da família (FIG. 6). A ameaça do desmoronamento mistura-se à ameaça do esquecimento. Após sua morte, a casa é finalmente destruída. Sua demolição soma-se a outras ruínas deixadas pelo progresso da cidade de Manaus. Todas elas tornam-se fragmentos a espera de uma nova interpretação da história. E é Nael, que para sobreviver, rememora e escreve a história daquela casa, da família que nela habitava, de Manaus, enfim, de suas origens, para que seja possível constituir-se como sujeito dotado de passado e de memória.

\section{Memória individual e coletiva}

Ainda que a narração de Nael represente sua visão particular e subjetiva do passado, ela se entrelaça às linhas que narram dramas sociais e históricos. Estes podem ser observados mais nitidamente nas inserções de imagens de arquivo, como aquelas que mostram as manifestações ocorridas nas ruas brasileiras após o golpe militar de 1964. A memória coletiva, acionada pelas imagens de arquivo, é associada às memórias de Nael através da urdidura da montagem. Por meio de transições, inserções e alterações de cor e textura, o drama histórico é entrelaçado à tragédia dos personagens. Como ocorre, por exemplo, no plano em que estudantes (reais e históricos) protestam contra o AI-5, portando um cartaz com o nome de Antenor Laval, professor e poeta, personagem ficcional de Dois Irmãos (FIG. 7).

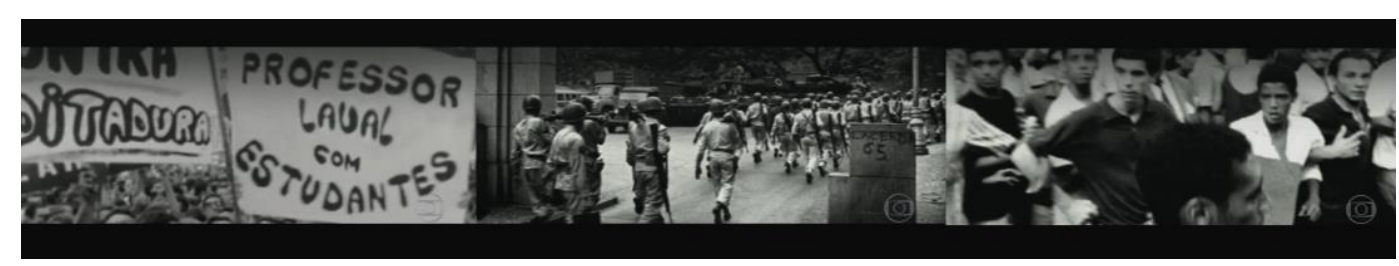

FIGURA 7. Frames de imagens de arquivo utilizadas pela minissérie para representar o embate entre militares contra alunos e professores do liceu de Manaus. FONTE: Dois Irmãos (Rede Globo, 2017)

A catástrofe familiar, desencadeada por uma sucessão de erros, reflete a catástrofe histórica. A tragédia manauara, abordada pela minissérie, engloba o desenvolvimento desorganizado da cidade a partir do ciclo da extração da borracha, passando pela ocupação 
militar e pelo golpe de 64 e concluindo-se na instalação da zona franca industrial. Esta última significou, ao mesmo tempo, o desenvolvimento da economia local e a decomposição da paisagem e de um modo de vida que vigorou na primeira metade do século XX. Em resumo, um drama familiar que espelha o drama social e histórico da cidade de Manaus e por metonímia, do Brasil.

Além de remeter a acontecimentos históricos, a minissérie acrescenta ao universo de Dois Irmãos diversas citações a outras obras, adicionando, assim, uma outra camada de intertextualidade e de memória coletiva, no sentido da exploração de um possível repertório compartilhado. No quarto e nas mãos de Nael, vemos livros de Carlos Drummond de Andrade, Machado de Assis, Manuel Bandeira, Charles Baudelaire. No liceu, já adulto e professor, Nael fala à classe sobre "Três Contos", livro de Flaubert. O cinema também é referenciado, como, por exemplo, na projeção de filmes mudos de Charles Chaplin, promovida por Estelita Reinoso. Cenas e cartazes de Limite, de Mario Peixoto, surgem nas paredes do bar freqüentado por Laval e seus alunos do liceu. Na praça onde ocorre o embate entre militares e estudantes, vemos rapidamente trechos de "Terra em Transe", de Glauber Rocha, além do cartaz de "Barravento", do mesmo diretor. Cada obra citada estabelece diálogos com cenas, personagens e temas abordados em Dois Irmãos, além de dialogar também com o repertório dos autores criadores da romance e da minissérie. Enfim, uma narrativa que parece incluir dentro dela referências e homenagens a obras que constituem a formação cultural do narrador, Nael, e dessa instância enunciadora implícita que representa os criadores da obra e de sua tradução, Hatoum, Carvalho e Camargo.

\section{Considerações finais}

De maneira geral, a minissérie Dois Irmãos parece optar por um realismo criativo que privilegia a forma da linguagem, embora mantenha algum compromisso com a reprodução do real. O tom operístico e barroco surge pintado em cores quentes, úmidas e viscerais nos gestos, na cenografia e no figurino. A trilha sonora mistura ópera, rock, MPB, música árabe, bolero, baião, entre outros. Uma reconfiguração do universo narrativo do livro, que tenta traduzir em imagens e sons a diversidade de sabores, sotaques, cores e humores de uma Manaus fictícia, mas que remete a aspectos de uma Manaus histórica durante boa parte do 
século XX. Mesmo compartilhando proximidades estéticas com outros projetos de Luiz Fernando Carvalho, Dois Irmãos é única em sua maneira de articular traços de autoria que traduzem um universo e uma poética singular.

$\mathrm{Na}$ minissérie, os procedimentos de roteirizarão, direção e realização dirigem suas forças e potencialidades para o desafio de traduzir o intraduzível. Nas palavras de Luiz Fernando Carvalho (2017, p. 24-25):

\begin{abstract}
Em termos de produção, a obra tem uma dramaturgia muito concisa, é quase uma peça de teatro. Isso facilita em termos de produção, mas não de realização. Realização é outra coisa. É saber como esses seis personagens ficam em carne e osso, passando por esse mundo emocional e a ação desse outro personagem invisível que é a memória e o tempo. Como incluir isso dentro de uma casa, uma cidade, os personagens contracenando com o tempo que escorre, que passa como um rio? $\mathrm{O}$ livro é um rendado de tempo, espaço, memórias, afetos, e a adaptação deve conseguir ser a síntese disso.
\end{abstract}

Mais que contar a história da rivalidade entre irmãos, a grande façanha da minissérie encontra-se em traduzir as reflexões acerca da memória em uma realização audiovisual. O uso da água como elemento catalisador da lembrança, da ruína como alegoria da memória esculpida pelo tempo, e o entrelaçamento entre memória individual e memória coletiva foram apontados como mecanismos relevantes da tradução poética de Dois Irmãos para o meio audiovisual. É nesse sentido que retomamos a ideia de que a versão televisiva do romance de Hatoum não se pretende uma mera adaptação do enredo do livro, mas configura-se como criação poética capaz de traduzir em imagem e som aquilo que no livro é pura sensibilidade: a ação do tempo e a necessidade de narrar o passado para ressignificar o presente.

“Os mortos, um dia, acabam morrendo de verdade”. É com essas palavras que Halim reflete sobre a força inexorável do tempo e do esquecimento. Nael, seu fiel ouvinte, é o sobrevivente bastardo encarregado de narrar suas lembranças e a dos outros personagens. Para tanto, ele se liberta do passado ao mesmo tempo em que o ressignifica através de suas palavras. O valor da narração encontra-se justamente no seu poder de "retomada salvadora pela palavra de um passado que, sem isso, desapareceria no silêncio e no esquecimento" (GAGNEBIN, 2013, p. 3). Nesse processo, salva-se o passado não apenas porque o registra, mas também "porque lhe assinala um lugar de sepultura no chão do presente, possibilitando o luto e a continuação da vida" (GAGNEBIN, 2014,p. 248).

A narração da memória em Dois Irmãos associa-se à metáfora benjaminiana "do rio que de romper a barragem do sofrimento para chegar ao mar, pressupõe o longo e penoso 
caminhar da memória, esse trabalho paciente e árido do lembrar" (GAGNEGBIN, p. 111, 2013). Assim é que, o narrador, consciente de seu poder, afirma a função do tempo e do esquecimento como agentes necessários para que seja possível criar novas narrativas sobre o passado. Na última cena da minissérie, vemos Nael navegar no rio. Seu percurso vai em direção ao encontro das águas do Rio Negro com o Rio Solimões. Águas que não se misturam, embora sigam o curso lado a lado. É nessas águas, e no curso da memória e da narração, que Nael apresenta sua derradeira reflexão:

\footnotetext{
Naquela época (da morte de Zana), tentei em vão escrever outras linhas. Mas as palavras parecem esperar a morte e o esquecimento. Permanecem soterradas, petrificadas em estado latente para depois, em lenta combustão, ascender em nós o desejo de contar passagens que o tempo dissipou. E o tempo que nos faz esquecer também é cúmplice delas. (HATOUM, 2017, p. 183)
}

Memória, esquecimento, narração e identidade são questões inseparavelmente ligadas ao tempo. Interpretado por Carvalho como um personagem em Dois Irmãos, o tempo é elemento essencial para o processo de rememoração, pois coloca em tensão passado e presente. A narração da memória dá novos significados ao passado e constitui sujeitos no presente. Se podemos chegar a alguma conclusão sobre a poesia da memória em Dois Irmãos, recorremos às palavras do velho Halim: é preciso narrar o passado para que "o tempo transforme nossos sentimentos em palavras verdadeiras."

\section{Referências}

BENJAMIN, W. Obras Escolhidas I. Magia e técnica, arte e política. Ensaios sobre literatura e história da cultura. São Paulo: Brasiliense, 2012.

Fale/UFMG, 2008.

A tarefa do tradutor: quatro traduções para o português. Belo Horizonte:

BALOGH, A. M. O discurso ficcional na TV. São Paulo: Edusp, 2002.

Conjunções, Disjunções, Transmutações: da Literatura ao cinema e à TV.

São Paulo: Annablume, 2004.

CADERNO Globo - Edição 11. Assista a esse livro. São Paulo: Globo Universidade, 2017.

Disponível em: app.cadernosglobo.com.br. Acessado em 5 de fevereiro de 2017. 
CAMPOS, H. “Da transcriação: poética e semiótica da operação tradutora”. In: OLIVEIRA, Ana Cláudia de; SANTAELLA, Lúcia (orgs). Semiótica da literatura. Cadernos PUC - 28. São Paulo: Educ, 1987.

Paulo: Perspectiva, 1992.

Metalinguagem e outras metas: ensaios de teoria e crítica literária. São

GAGNEBIN, J. M. História e Narração em Walter Benjamin. São Paulo: Perspectiva, 2013.

editora 34, 2014.

. Limiar, aura e rememoração. Ensaios sobre Walter Benjamin. São Paulo:

MILTON, H. Dois Irmãos. São Paulo: Companhia das Letras, 2017.

PLAZA, J. Tradução intersemiótica. São Paulo: Perspectiva, 2013.

RIBEIRO, Daniel; SANTAELLA, Lucia. "A arqueologia benjaminiana para iluminar o presente midiático”. In: MUSSE, Christina; VARGAS, Herom; NICOLAU, Marcos. (org.) Comunicação, mídias e temporalidades. Brasília: Compós, 2017. No prelo.

STAM, R. "Teoria e prática da adaptação: da fidelidade à intertextualidade". In: Ilha do Desterro A Journal of English Language, Literatures in English and Cultural Studies, n. 51, p. 019-053, 2006.

\section{Referências audiovisuais}

DOIS irmãos. Direção: Luiz Fernando Carvalho. Roteiro: Maria Camargo. Realização: Rede Globo, 2017. 